\section{Chile, historia de una memoria: de la sombra del General al recuerdo y a la justicia}

Chile, history of a memory: from the General's shadow to remembering and justice

\section{Josefina Cuesta-Bustillo*}

\section{Resumen}

Las dictaduras latinoamericanas, especialmente las del Cono Sur, suscitaron un enorme interés en la opinión publicada europea. Este artículo presenta una primera aproximación a la historia de la memoria de la dictadura y de la transición chilenas en las páginas de la prensa francesa (1990-2003). En ella laten los trabajos de la memoria -olvido, recuerdo, silencio, cambio, sustitución, superposición, de construcción/ destrucción del mito/contra-mito del dictador-, y puede analizarse cómo se entretejen las diversas relaciones entre los tiempos históricos en los diferentes discursos y ante la evolución de los acontecimientos, y cómo la memoria ha sido un actor fundamental en los diferentes grupos y opciones políticas en la transición a la democracia. El caso chileno ofrece muchos puntos de comparación -aunque implícitos aquí- con otras dictaduras y transiciones del Cono Sur e ibéricas, especialmente con la española.

Palabras clave: dictadura, transición, Chile, opinión publicada, prensa francesa

\begin{abstract}
This article presents an exploratory research of the history of the memory of the Chilean dictatorship and transition to democracy in the French press (1990-2003). The different aspects of remembering such as forgetting, silencing, changing, substituting, overlapping, constructing/destroying the myth of the dictator, are traced as well as the interaction between the discourses of different historical periods as events evolved. It is showed that collective memory was a principal actor among political groups during the transition. The Chilean case offers many points of comparison, although implicit in this presentation, with other dictatorships and transitions in Latin America and the Iberian Peninsula, especially, the case of Spain.
\end{abstract}

Key words: dictatorship, transition, Chile, Public opinion, French press 


\section{Introducción}

El 11 de setiembre, el general Pinochet expulsaba al Presidente Salvador Allende. Asesinatos, torturas y crímenes de todo género: la policía militar torturaría durante largos años. Hasta la elección de 1989, de un presidente demócrata-cristiano. ¿Había llegado el tiempo de la reconciliación y del perdón? El debate es público. Pero el discurso del General en jefe, siempre presente, no cambia'.

\section{Los "años negros" de Chile}

El "interminable paréntesis de humanidad" que fue la dictadura chilena de 1973 a 1989, se prolongó en la transición a la democracia, siempre bajo la sombra omnipresente de Augusto Pinochet (Huneeus 2014). Éste no sería inquietado en su propio país, al que había impuesto un proceso de silencio, especialmente destinado a borrar los atentados contra los derechos humanos (Riquelme 1999: 22-25; Franco 2006: 58-65; Harmer y Riquelme 2014). Las condiciones específicas de esta transición en Chile, anclada en la hipoteca del presente al pasado, respondió entre otros factores a la supervivencia del dictador dentro del poder militar y a la pervivencia de su base social de apoyo, que representaba a un tercio del total de la población y se mantendría estable hasta fin del siglo XX.

La dictadura de Pinochet (Alcázar 2013; Hoppe, López, Montecino y Pérez 2013), antes de su sustitución por un gobierno democrático, además de preservar determinados poderes por la vía constitucional, arbitró un sistema jurídico que impidiera toda persecución judicial a los autores de la intensa represión aplicada

"En Chile, el olvido obstáculo al perdón", La Croix, 25 octubre 1995 (En adelante citado como LC). entre 1973 y 1978. El decreto-ley 2191, de 19 de abril de 1978, reforzado por otras "leyes de amarre" (Barahona 2002: 213), dictadas durante el periodo electoral, hacían más invulnerable el aparato de poder establecido por la dictadura. Amnistía queamparabaalos crímenes cometidos durante la dictadura. Esta política de amnesia y de amnistía no impidió que, bajo un lema oficial de olvido y de reconciliación, se cobijara un conflicto en la sociedad chilena, en la que, mientras aquellos pugnaban contra el recuerdo y la verdad, otro sector social los reclamara y se organizara, con dificultades y con cierto temor. Eran, entre otros, las organizaciones de derechos humanos, las víctimas de la dictadura, los desaparecidos y sus familiares parecían reducidos al silencio desde el golpe. Aunque no del todo (Finet y Desvois 2014). Se negaron al olvido y organizaron solidariamente su recuerdo y la lucha por la justica en varias asociaciones como la Agrupación de familiares de detenidosdesaparecidos. Después de veinte años, sus objetivos no habían cambiado:

(...) queremos saber qué ha sido de nuestros padres, de nuestras familias. No tenemos ninguna información (...) ¿Dónde fueron internados? ¿Cómo murieron? Merecen una sepultura decente (LC 1995).

En 1995 el periódico católico La Croix desde Francia, como un altavoz de las nuevas Antígonas (Steiner 2004; Bollack, 1999; Duroux y Urdician, 2010).

Reivindicaciones que se extendían al cuerpo, a la sepultura, al duelo, al recuerdo, a la verdad. También las Organizaciones Internacionales, o las ONG, como Amnistía Internacional², Human

Ver Informes Anuales de Amnistía Internacional: https://www. amnesty.org/es/; http://amnistiainternacional.org/ 
Rights Watch ${ }^{3}$ o el equipo Nizkor ${ }^{4}$ venían alzando su voz y su denuncia contra el silencio. Ahí están sus Informes, especialmente desde 1975 a 1979, que bien merecen un estudio más detenido.

Dos (o varias) políticas de la memoria habían permanecido frente a frente: la del recuerdo, defendida tímidamente por las víctimas y en el exilio (Chaves Palacios 2010; Stern 2010; Buriano, Dutrénit y Vázquez 2015), y la de la amnistía y el olvido, apoyada por los victimarios, cobijados bajo la impunidad, y por los grupos sociales acomodados y beneficiados por el "milagro económico" (Gárate 2012; Gómez Leyton 2010).

\section{De la esperanza a la desesperanza, el olvido (1990-1995)}

"El camino de la justicia se vio erizado de obstáculos" (Barahona 2002: 212), a pesar de que los caminos a la democracia chilena parecieron abrir una puerta a la memoria y a la esperanza.

Cuando Chile empezaba su proceso de transición gozaba de conocer las experiencias de Argentina, Uruguay y Brasil (Barahona 2002: 210; Rojas Mix 2005: 14-23; Rojas Mix 2007).

Tras la derrota (parcial) del dictador Pinochet, el presidente democrático elegido en 1990, Patricio Aylwin, había anunciado su compromiso ineludible con la defensa de los derechos humanos. Además,

¿Cómo olvidar sus lágrimas cuando, ante las cámaras de televisión, evocó los 3.500 muertos de la dictadura nacida

https://www.hrw.org/es. (Consultado 10 junio 2016).

http://www.nizkor.org/; http://www.derechos.org/nizkor/; http:// www.radionizkor.org/usa/. (Consultado 10 junio 2016). del golpe de Estado del 11 de setiembre de 1973 y pidió perdón a la nación? (LC 1995).

Recordaba La Croix de este demócrata cristiano.

La Concertación, como es sabido, coalición dirigida por Patricio Aylwin, había previsto abrogar la ley de amnistía e iniciar procesos 'con la mayor diligencia posible'. Pero múltiples factores redujeron la actuación del nuevo gobierno: la moderación impuesta por la transición negociada, el apoyo (y el poder) de que gozaba Pinochet y la identificación de las fuerzas armadas con él, las barreras jurídicas y constitucionales, la hostilidad de una parte del poder judicial, especialmente del Tribunal Supremo e, incluso, los atentados perpetrados por la extrema izquierda (Garretón 2012). La problemática del poder judicial no nacía ahora (Lefranc 2002: 44; Barahona 2002: 212; Lira y Loveman 2014). El poder judicial y el Tribunal Supremo se oponían a la verdad, a la justicia y al recuerdo (Barahona 2002: 214). En vista de esta realidad, el presidente se limitó a exigir justicia. Establecía lo que en adelante se conocería como la doctrina Aylwin "en la medida de lo posible" (Barahona 2002: 212).

'Consecuente con su promesa', además de las vías judicial y parlamentaria, como es sabido, el presidente Aylwin nombró el 25 de abril de 1990 una Comisión para la Verdad y la Reconciliación, de carácter pluralista y no partidista, consensual e imparcial. Aquel había explicado, dos días antes, la tarea que le asignaba:

Cerrar los ojos a lo que ha pasado e ignorarlo como si nada hubiera pasado prolongaría indefinidamente una fuente durable de dolor, de división, de odio y de violencia en el corazón de nuestra sociedad. Sólo el esclarecimiento de la verdad y la búsqueda de la justicia crean el clima moral indispensable a la reconciliación y a la paz (LC 1995). 
El gobierno chileno había optado por el establecimiento de una verdad histórica, oficialmente sancionada y susceptible de sustentar un amplio consenso social y político. El trabajo de la Comisión para la Verdad y la Reconciliación es bien conocido (Lefranc 2002: 43). En ella no se hacía mención a la justicia reclamada por las víctimas, por sus familiares y porsus asociaciones. ¿Era la impunidad un precio de la democracia en América Latina, desde los años ochenta, como había sucedido en España? A pesar de la resistencia de las fuerzas armadas a su trabajo -recordemos que solo testimoniaron dos militares en servicio activo- (Cavallo 1998: 87; Lefranc 2002: 47), y de su consabida obstrucción de negar la comunicación de los documentos o de hacerlos desaparecer. A pesar de sus limitaciones, el resultado de la Comisión logró un amplio consenso, que acaso era el objetivo fundamental de ésta, rechazado especialmente por las fuerzas armadas. Aunque este consenso duró poco, pues un nuevo atentado, en 1991, radicalizó a la derecha, en su Informe quedaba establecida 'la responsabilidad moral del Estado' y la de la institución militar, realizaba una severa crítica al sistema judicial y a su débil defensa del derecho de las víctimas, establecía una verdad ampliamente consensuada e inauguraba, en palabras del presidente, "el tiempo del perdón y de la reconciliación". Y si bien, algún miembro del anterior gobierno dictatorial sostenía que en éste "nadie había reparado en las dimensiones de la violación de los derechos humanos", Pinochet afirmaba que

(...) el ejército de Chile no (veía) ciertamente ninguna razón de pedir perdón, por haber tomado parte en una tarea patriótica (del restablecimiento de la paz social y de la democracia) (Lefranc 2002: 48)5.

Sergio Díez, senador de Renovación Nacional y exministro de la dictadura, en La Época, 9 de junio de 1990, citado por Sandrine Lefranc.
En la opinión chilena, el $26 \%$ consideró que a la democracia chilena le faltaba el juicio a los responsables de la violación de los derechos humanos, aunque el $67 \%$ sostenía que el terrorismo representaba, junto con la delincuencia, la principal amenaza para esta democracia (Garretón Merino, Lagos y Méndez 1994).

En 1994, cuatro años más tarde, un nuevo presidente, del mismo color político, Eduardo Frei (Fermandois 2013-2015), parecía aprestarse a consolidar la democracia. En 1995, el juicio a Contreras parecía corroborar esa política. Los Estados Unidos, que habían apoyado antaño a la dictadura (Massardo 1999: 3-8), impulsaban ahora a sus viejos aliados a aplicar la justicia.

Pero la realidad no alcanzaba las expectativas. Contreras se refugió en un hospital de la Marina, sustrayéndose a la justicia durante cinco meses. Pinochet calificó el juicio de 'injusto' y uno de sus fieles vituperaba en el aniversario del golpe de estado -y lo recogía el órgano católico francés que seguía de cerca la transición chilena:

El 11 de septiembre marca el retorno a la libertad en Chile. Los que ayer preparaban la guerra civil, hoy se ofenden. Los asesinos son ellos. Que cese la persecución de las fuerzas armadas. Es hora ya de decir "basta". Lo que nosotros queremos es construir un país de primera clase. Esto requiere inteligencia, capacidad y olvido (LC 1995) ${ }^{6}$.

Con el pretexto del silencio, todo el discurso pinochetista buscaba desviar la mirada del pasado, deslumbrada por los considerados logros del presente y hacia el futuro.

Habían abundado los discursos sobre el olvido en muchas de las transiciones. Pero también la

\footnotetext{
“En Chile, el olvido obstáculo al perdón”, La Croix, 25 octubre 1995 (El subrayado es nuestro).
} 
lucha contra él. En la edición de los textos de un Coloquio celebrado en París conjuntamente en el Senado y en la Cámara de Diputados, sobre la Política de desaparición forzada de personas, se incluyó un Postfacio de Julio Cortázar titulado "Negación del olvido", donde clamaba:

Pero precisamente por eso, porque en este momento tocamos fondo como jamás lo tocó nuestra historia, llena sin embargo de etapas sombrías, precisamente por eso hay que asumir de frente y sin tapujos esa realidad que muchos pretenden ya dar por terminada, Hay que mantener, en un obstinado presente, con toda su sangre $y$ su ignominia, algo que ya se está queriendo hacer entrar en el cómodo país del olvido (Mignone y Mc Donell 2006: 88).

La rebelión de los militares contra la justicia se parapetaba en el olvido. Apoyado en ese discurso de "justicia el revés" tan divulgado también en España durante la dictadura franquista (VV. AA. 1990). Se seguía justificando el hábito de matar al adversario político, según afirmaría Libération, el periódico izquierdista francés el 4 de noviembre de 1998. La chilena seguía siendo una "democracia protegida por los militares". "La herencia de la dictadura impide hacer justicia", admitía Guillermo Miranda, presidente de la Comisión Internacional del Partido Socialista Chileno. Otros la denominarían como "democracia delegativa" o "de baja intensidad" (Varas 2012 y Huneeus 2014).

El problema de la memoria y de la justicia estaba plateado en la sociedad chilena con toda su crudeza en los años noventa (Salazar 2012). Olvido, era el programa de los militares y de los torturadores durante el régimen dictatorial, mientras las víctimas se refugiaban en el propio recuerdo, con dificultades para salir del silencio: 'necesaria palabra, pero difícil palabra', se podía leer en la prensa europea. Asociaciones e individualidadesreclamabanjusticia. El programa oficial se conformaba con la 'reconciliación'.
Una reconciliación polisémica, tramposa, pues no quería decir lo mismo en todas las bocas y su contenido variaba según la posición política y la experiencia personal y política de quien la pronunciara. El nuevo presidente, Frei, en 1994 se vería obligado a exclamar: "el país no está reconciliado". Las posturas en relación al perdón eran, consiguientemente, demasiado complejas.

\section{La justicia que viene del exterior (1995- 1998)}

Esta transición 'vigilada' de la amnesia y el olvido impulsó a algunos exiliados a buscar la justicia en otra parte. No era la primera vez que la justicia venía del exterior. Ya en 1976, el atentado contra Letelier en Washington obligó a intervenir a la justicia norteamericana (Lawner 2011).

Aunque los Estados Unidos apoyaban directamente a la dictadura chilena, era el primer atentado terrorista de este carácter que se producía en su suelo. El juicio norteamericano a los autores puso en juego a la justicia chilena, que extraditó al encausado, Michael Townley que entonces residía en Chile, acusado de ser autor material del asesinato. En el juicio celebrado en 1979 en Estados Unidos, éste acusó a su vez al poder dictatorial chileno, a la DINA, y a su jefe, Contreras. La prensa occidental se haría eco de ello.

Pero habrá que esperar a 1995 a los juicios en Chile contra Contreras y Espinoza, acusados respectivamente de los asesinatos de Letelier en Washington y del general Prats en Buenos Aires. En esta fecha de 1995, también los Estados Unidos presionarán a la justicia chilena 
para encausar al director de la DINA. Como es sabido, en el juicio, Contreras revirtió la acusación contra Pinochet como responsable, hecho muy divulgado por la prensa y que alcanzó una gran resonancia. Era la primera vez que se quebraba la 'ley del silencio' en el seno de la institución militar.

"El barniz caqui comienza a resquebrajarse", ironizará poco después en Francia Le Nouvel Observateur?. El hijo de Orlando Letelier, a la sazón diputado socialista, manifestará esperanzado al semanario que acabamos de citar:

Se trata del primer documento que prueba la responsabilidad de Pinochet en el asesinato de mi padre. Muestra, igualmente, que ha habido obstrucción de altos responsables del ejército en el marco de los procedimientos judiciales (LNO 25.5.2000).

También el hijo de Pinochet, por su parte, se sentirá obligado a defender a su padre, difundiendo la imagen de 'gran político', de 'salvador' de Chile y su política anticomunista. La memoria había comenzado a ser enarbolada por la generación de los hijos. Desde 1995 y con el inicio de la justicia a la dictadura en Chile, en 2000 , la segunda generación se incorporaba a la edificación de la memoria de los protagonistas (Juliá 2004; Cuesta, 2007). 'Los dictadores envejecen, los muertos permanecen jóvenes' recogía la prensa francesa. A los sonados juicios de 1995, en 1998 seguiría el arresto londinense del dictador.

Diez años después de la implantación de la democracia en Chile, el dictador y senador vitalicio, apoyado en su impunidad, se encontraba en gran Bretaña, como es

Le Nouvel Observateur, 25 de mayo 2000 (en adelante LNO). conocido. El recuerdo, el testimonio y la denuncia 'reclamaban justicia en Europa', y el viejo continente, defensor de la doctrina de los derechos humanos, puso en movimiento sus aparatos jurídicos. Ya en 1990 se había juzgado en Francia a Astiz, torturador argentino de la ESMA, condenándolo en rebeldía, acusado de la desaparición de dos monjas francesas, tema que llenaría muchas páginas en la prensa gala. Ahora, los testimonios de las familias de desaparecidos chilenos encontraron el apoyo del brazo de la ley en un juez español, primero -otros jueces de Europa Occidental se le unirían después, en Francia, Suiza, Suecia-, y en la justicia inglesa después. "Hoy el tirano tiembla en su lecho de Londres", escribió Libération el 4 de noviembre de 1998.

Desde entonces, toda la prensa europea siguió, como una historia preñada de suspense, el episodio londinense. Más que de un hecho, podríamos definirlo de acontecimiento. Fue denso en significados. Retendremos aquí sólo los conflictos que generó en los amplios campos de la memoria y de los derechos humanos.

En efecto más allá de su resolución final, la acusación a Pinochet y su retención en Londres habían alcanzado una gran resonancia. Desde la historia de la memoria importan, sobre todo, el debate y los argumentos que generó. Gladys Marín, secretaria general del Partido Comunista chileno, había acusado a Pinochet en enero de 1998 de la desaparición de su esposo, justo ocho meses antes de su arresto londinense. Arresto que quedará en la memoria chilena y europea como un hito sin retorno. Las denuncias en su propio país, la palabra de las víctimas y de sus familiares, el protagonismo de la justicia chilena, todo parece arrancar de ahí. El recuerdo había apelado a la justicia quebrando 
el modelo de transición pacífica sin juicio para el dictador. Tuvo el valor y el significado de revelar como posible lo inimaginable -la detención del general-, la vulnerabilidad de éste, su reducción a la categoría de una persona normal, susceptible de ser sometida a instituciones civiles. Quebró, además, la voluntad que éste había impuesto: la de matar el cuerpo en el pasado y, al hacerlo desaparecer, matar también su recuerdo y su recuperación en el presente. Quebró los argumentos y los sustantivos, cuando se invocaron razones humanitarias -de edad, de salud-, a favor de la imprescriptibilidad en su caso. Manuel Vazquez Montalbán lo formuló en una frase, apuntado al núcleo de la cuestión: "¿Razones humanitarias? No es un anciano de 82 años, es un dictador de 82 años". Quebró fronteras -nacionales, entre otras- ante la impunidad del crimen contra la humanidad y lanzó una señal de amenaza para los autores de este tipo de crímenes.

\footnotetext{
En 2013, Hugo Relva, consejero jurídico de Amnistía Internacional para temas de justicia internacional [...], comentó a nuestra emisora que la detención en Londres de Pinochet constituyó una verdadera revolución en el derecho penal internacional, dejando en claro que la extraterritorialidad de la persecución de crímenes de lesa humanidad, es un principio intransable (Candia 2013).
}

Pues amplió de golpe, los escenarios desde donde reclamar justicia y donde argumentar la imprescriptibilidad. Suscitó, en fin, una cuestión jurídica, ética y política a los gobiernos de los Estados europeos: La imprescriptibilidad ies una cuestión de tiempo o de memoria? La cuestión había desbordado a Chile y acuciaba en Madrid, Londres, París, Roma, Berna u Oslo. Provocó la intervención conjunta -y el conflicto, a veces- entre jurisdicciones supremas de los Estados miembros de la Unión Europea -la Audiencia Nacional española y el Alto Tribunal y la Cámara de los Lores, en Londres- o, dentro del propio país, la distonía entre jueces y políticos. Supuso, al menos teóricamente, un éxito para la doctrina de los derechos humanos $y$, sobre todo, para los defensores del recuerdo, de las víctimas y de la justicia.

La causa contra Pinochet en Londres relanzó, además, el debate sobre el juicio de los crímenes contra la humanidad, tuvo el mérito de popularizar el combate contra la impunidad y de hacer más palmaria y urgente la necesidad del Tribunal Penal Internacional, cuya constitución quedó establecida ese mismo año en Roma. Puso de relieve la importancia de preservar los archivos de la represión para el conocimiento de las responsabilidades y para el establecimiento, judicial o no, de la verdad. (González Quintana 2009).

En ese efecto encadenado de recuerdo, juicio, justicia y jurisdicciones, todo un pasado se agolpó en este proceso europeo. La memoria y la información se remontó desde la herencia del juicio de Núremberg -o Tokio-, a la resolución de 13 de febrero de 1946 de la ONU, a los tribunales especiales para Ruanda o para la ex-Yugoslavia, o a los procesos de Barbie, Touvier y Papon, con los que le emparentaba el paralelismo en cuestiones de encausado y ancianidad (Lambert 1991; Jean y Salas 2002; Bédarida 1996; Valla 1996). Todos estos elementos y otros pusieron sobre el tapete "¿Qué hacer con Pinochet?”. La Croix invocó la resolución de la ONU, ya citada, que recomienda a todos los Estados tomar medidas para que sean reprimidos los crímenes contra la humanidad. De ahí la importancia de este, "(...) acontecimiento jurídico histórico, porque por

\footnotetext{
"Le devoir de mémoire". Editorial de Le Monde, 29 octubre 1998 Le Canard enchaîné, 28 octubre 1998.
} 
primera vez los grandes principios consagrados en las Convenciones internacionales se ponen en práctica ${ }^{9}$.

Lo mismo afirmaban también los abogados de las familias de las víctimas ${ }^{10}$. La opinión publicada no dejaba de reconocer que los obstáculos no eran escasos, se argumentaron varios de orden jurídico: ¿Se beneficia Pinochet de la inmunidad diplomática, como defiende su país? ¿Las quejas y denuncias son admisibles? ¿Los crímenes son imprescriptibles? ${ }^{11}$

Al abrir el proceso, la justicia pudo contribuir, en el tiempo corto, a fragilizar la renovación democrática en Chile, que reposaba en el pacto de 'democracia con olvido', algunos así lo pretextaron. Las víctimas y una gran parte de la sociedad europea se pronunciaron por el "deber de memoria", como tituló Le Monde su artículo editorial del 29 de octubre de 1998, y por "establecer la verdad". La sociedad chilena estaba dividida. Todos la reclamaban en su favor. También el propio Pinochet: "Espero que se hará justicia a mi memoria"12. La frase no tiene desperdicio, pivota sobre dos conceptos fundamentales en juego: justicia y memoria, en este caso invocados por el dictador en su propio beneficio. Es interesante constatar cómo, llegado el momento, los victimarios, autoconvertidos en víctimas, pueden apropiarse del discurso de éstas en beneficio propio. El silencio y el olvido lo aprovechan las clases altas, más ocupadas en el milagro económico, también las clases medias están prestas a olvidar los crímenes de la dictadura, para defender mejor

\footnotetext{
La Croix, 31 octubre 1998.

$10 \quad$ La Croix, 31 octubre 1998.

11 Le Canard enchaîné, 28 octubre 1998.

12 Le Monde, 29 octubre 1998.
}

sus intereses políticos, se afirmaba en Politis ${ }^{13}$. $Y$ los grupos desfavorecidos, atenazados porque necesidad obliga. La suerte de Pinochet apenas interesa al $30 \%$ de los chilenos, pues los otros, a consecuencia de su dictadura, viven en la pobreza o en el umbral de la miseria.

Un olvido semi-voluntario había quedado agazapado, mitad silencio, mitad hueco de la memoria, en la sociedad: "Chile ha estado largo tiempo paralizado por el miedo"14.

Algo había cambiado. Frente a la impunidad, establecida como lema, se enarbolaba un nuevo lema: "ni olvido, ni perdón", como tituló Le Figaro ${ }^{15}$. Pues hasta ahora, la rememoración de la dictadura había quedado envuelta en el temor a hablar, temor agazapado en una sociedad en la que el recuerdo se transformaba en miedo: "Debíamos aterrorizar al pueblo para impedir que se sublevara. El recurso a la tortura era sistemático y las órdenes venían del más alto nivel", había confesado en 1989 el propio Manuel Contreras, antiguo jefe de la DINA, como hemos señalado. "Desde hace dos años, el país ha comenzado a comprender lo que ha pasado: pero esta desaparición del miedo es aún muy frágil", afirmaba Gladys Díaz, periodista chilena ${ }^{16}$. Ésta era la imagen que se recuperaba desde Europa. "Los cadáveres empiezan a surgir de las fosas y los torturados a salir de los armarios".

Comenzaba a sonar la hora de la verdad para la democracia chilena, que descubría las lagunas

\footnotetext{
Politis, 28 enero 1999.

14 Ibíd.

15 Le Figaro, 18 octubre 1998.

16 Periodista torturada por la dictadura que presentó su testimonio en España. Libération, 14-15 noviembre 1998.
} 
de una transición inacabada, recubierta con la piel de cordero de la 'reconciliación nacional'. A pesar de los esfuerzos de 'pasar la página', en esta transición vigilada, el recuerdo de la dictadura retornó con fuerza en Chile. "Se ha hecho la prueba de que Pinochet no era intocable, y esto nos anima a proseguir nuestro combate". Con este acontecimiento quedaba socavado este 'mito de la reconciliación', que no resistiría ante la justicia, y que había sido puesto en entredicho por el arresto de Pinochet: "No habrá reconciliación sin verdad, ni justicia. Es necesario saber dónde están los cuerpos de los desaparecidos. Los militares deben reconocer sus actos, pedir perdón e ir a la cárcel", afirmaba Gladys Díaz y Libération lo divulgaba ${ }^{17}$. Como en otras latitudes, el proceso de Pinochet había permitido el retorno de un pasado rechazado, con los mismos antagonismos, ahora brutalmente "desbridados"18. Incluso los Estados Unidos, por boca de Magdalena Albright, reconocieron sus "terribles errores" en América Latina (Amira 1981: 279; Comité de Santa Fe 1990: 90-103; Moulian 1997).

Hicieron oír su voz especialmente dos sectores políticos que reclamaban el recuerdo, aunque con distinto énfasis. Reclamaron justicia, sin eufemismos, las víctimas y sus familiares, el Partido Comunista (Alvarez Vallejos 2011) y la izquierda del Partido Socialista chilenos. Una torturada reclamaba: "los militares deben reconocer sus actos, pedir perdón e ir a la cárcel; es necesario saber dónde están los cuerpos de los desparecidos", y "no habrá reconciliación sin verdad ni justicia"19. Por otra parte, el resto del Partido Socialista y la Democracia Cristiana, que

\footnotetext{
Gladys Díaz en Libération, 14-15 noviembre 1998.

18 Libération, 14-15 noviembre 1998.

19 Libération, 14-15 noviembre 1998.
}

constituían la mayoría (un 62\%), que ocupaba el poder y que se mostraba favorable a reducir la amnistía que protegía a los militares, "estiman que es preciso establecer la verdad y juzgar a los responsables" ${ }^{20}$. Partidarios, unos y otros del quebrantamiento del olvido y de la apertura de los caminos de la memoria, iniciarían una senda sin retorno.

El proceso de Londres suscitó también la mirada crítica de la izquierda hacia la democracia chilena: ¿qué democracia? ¿Qué libertad? Este acontecimiento permitía revisar públicamente el discurso que se venía propagando de la dictadura y de la transición a la democracia, el modelo de "Concertación" que sustentaba un programa de "reconciliación nacional", ensalzado por los media, por los estados occidentales, por los social-demócratas y por la comunidad económica internacional, representada por el FMI y por el Banco Mundial. Se recordaba la denuncia formulada por Eduardo Galeano, que ponía voz a ese $30 \%$ que se debatía en la pobreza:

\section{“(...) el éxito chileno es uno de los más injustos del mundo: $20 \%$ de la población acapara el $62 \%$ de la riqueza; la única transición posible de la dictadura a la democracia vigilada fue la de una injusticia a otra injusticia" (Constable y Valenzuela, 2013) ${ }^{21}$.}

La derecha no pudo impedir la información, la historia, la verdad que desbordaba las fronteras del propio país. Optó por sembrar el miedo: argumentaba que el recurso al pasado amenazaba al presente y al futuro, que los peligros amenazaban la democracia, también los externos, pues la actitud de los jueces europeos, tanto españoles como británicos,

\footnotetext{
L'Express, 12 noviembre 1998.

21 Politis, 28 enero 1999.
} 
suponían una coacción a la soberanía de la patria. Presentaba esta justicia, venida de Europa, como una justicia de ricos, de blancos, y señalaba el riesgo de los efectos perversos del empeño desconsiderado de perseguir a Pinochet en el continente europeo. Se divulgó, incluso, que se había impulsado la resurrección de un grupo de extrema derecha ${ }^{22}$ que acentuó el distanciamiento entre España-Chile y que borró el recuerdo del país ibérico durante dos largos años. Los defensores de Pinochet tampoco se ahorraron remitir a España a su pasado franquista y recriminarla al pretender juzgar a dictadores extranjeros cuando no lo había intentado con el propio, o "aconsejarla que antes debería barrer su propia puerta" ${ }^{23}$.

El partido de Renovación Nacional proclamó un nuevo "acuerdo nacional", aceptando la búsqueda de desaparecidos; una abogada del mismo partido intentaba mostrarse conciliadora, mientras exaltaba la figura del dictador, según Libération:

"La derecha tiene que reconocer que Pinochet no ha terminado como dictador, sino como hombre de honor y de derecho, artífice decisivo de la democracia. Él tiene su parte en la negociación. Pero también es necesario aclarar lo que ha pasado, ha habido muertos y desaparecidos. Las familias tienen derecho a saber dónde están enterrados los cuerpos de los suyos" 24 .

También los militares adaptaron su conducta. En 1999, ante la debatida cuestión de si se procesaba a Pinochet en Europa o se le extraditaba a Chile, aquellos aceptaron formar parte de una comisión encargada de arrojar luz sobre la suerte de los desaparecidos durante

22 Nacional Hebdo, 6 abril 2000.

23 Le Monde, 21 noviembre 1998.

24 Libération, 15 noviembre 1998. la larga dictadura (1973-1990) (García Castro 2011). Tomaron esta decisión cuando se acababa de levantar la inmunidad parlamentaria aPinochet, como senador vitalicio, que suscitaría el descontento del ejército. Reconocieron la existencia de violaciones de los derechos humanos, a las que denominaron "excesos", aunque negaron que respondiera a una "política sistemática"25.

\section{Aniversario veinticinco del golpe de estado, se abre la puerta al recuerdo de Allende (1998)}

El arresto del dictador había coincidido con el aniversario veinticinco del golpe, una fecha emblemática que no dejará pasar de largo la prensa europea. Desde el juicio por el asesinato de Letelier, se conocían ya documentos secretos de la CIA que, ahora, veinticinco años después, saltaron a las páginas de la prensa francesa de izquierdas, que fue la primera en reivindicar el recuerdo de Allende (Garcés 2013). Aunque no gustará en Estados Unidos. Libération dedicó un amplio dossier a la historia chilena, que se remonta hasta 1970, Allende representa la primera figura. Con él se recordó a medio millón de exiliados, a los diez mil muertos y desaparecidos -según algunas fuentes-, de ellos tres mil documentados y entre los que se cuentan más del millar de desaparecidos; también son divulgados los tristemente célebres lugares de reclusión y de tortura y los tipos de ésta. La sociedad civil y la opinión publicada europeas se despiertan lentamente: "Chile saldrá vencedor si se purifica en la verdad, no en la mentira de las atrocidades del pasado",

El tema interesó a la prensa europea: Le Monde, 12 de mayo y 16 de junio 2000, The Economist, junio 2000. 
escribió Carlos Fuentes en Le Monde ${ }^{26}$. También los obispos chilenos promovieron la búsqueda de la verdad y de la justicia, valores a los que añadirían, en su declaración de 20 de noviembre de 1998, la reconciliación y el perdón.

Entre la verdad y la negación se colaban, a veces, mixtificaciones. Luis Sepúlveda denunció algunas en la prensa francesa. Debatía la perspectiva defendida por Jorge Edwards, según el cual la desventura de Pinochet había producido un "seísmo de las memorias $\mathrm{y}$, al mismo tiempo, una fijación y un retorno de imágenes que se creía enterradas". De nuevo reaparecía el temor de recuperar el pasado. Los que lo habían rechazado se veían ahora obligados a mirar hacia atrás, "Las estatuas de sal", había titulado su artículo Edwards, título que dejaba traslucir un cierto sentido peyorativo del recuerdo. En contraposición, las víctimas no habían olvidado -afirmaba Sepúlveda, que era una de ellas-, los familiares habían sido privados del cuerpo y de la justicia y los jóvenes privados del derecho a una memoria histórica. "Estamos obligados a mirar hacia atrás, a hurgar en nuestro pasado reciente, incluso a costa de nuestro cuerpo"27. Y frente a la impunidad, defendía que sólo el valor que se funda en el coraje civil, cívico, civilizado, podría fortalecer la democracia con el 'juicio al tirano'. Estos textos de dos escritores bien conocidos, guardianes de sendas memorias encontradas, eran ambos expresión de la división de la sociedad chilena: "Nuestra pesadilla no ha terminado, la vuestra acaba de comenzar" recordaba Sepúlveda a Edwards $^{28}$. Dos tiempos históricos de distinta

\footnotetext{
$26 \quad$ Carlos Fuentes. 1999. "Chile debe purificarse de la deshonra de Pinochet", Le Monde, 3 febrero.

27 Luis Sepúlveda, Le Monde, febrero 1999.

28 Luis Sepúlveda, Le Monde, febrero 1999.
}

dirección se encontraban en el presente: olvido del pasado apelando al futuro, defendido por unos, frente a la recuperación del pasado, propugnado por víctimas y por la izquierda. También dos lenguajes, dos realidades, dos sociedades: "para unos la justicia se llama justicia, para los otros se llama 'consecuencias imprevisibles' para el campo económico”29.

Como había sucedido después de las dictaduras europeas de la segunda Guerra Mundial, más allá de los juicios históricos y del destino de las personalidades políticas, la mayoría de los ciudadanos tardó tiempo en mirarse al espejo y en reconocer su verdadero rostro, sobretodo el de la colaboración (Rousso 1987a; 1987b; Rousso, Conan 1994; Morales, 2005: 12-13). Exponente de la memoria de una mayoría era el psicoanálisis colectivo expresado por M. A. de la Parra:

(...) lo que es importante, y no se sabe aquí [en Francia], es decir que la mayoría de los chilenos no han reaccionado ante la dictadura, que las conciencias han sido compradas y que el país quedó quebrado (Parra 1999) ${ }^{30}$.

Y no puede silenciar la herencia de miedo y de vergüenza: "Usted nos ha domesticado por el miedo". Herencia que, considera, asumió la clase media, que aprendió a vivir bien en la confortable indiferencia del liberalismo y que le hace reclamar al dictador: "Usted nos ha convertido en superficiales, hasta liquidarnos". Este psiquiatra analizaba su trayectoria, y con ella la de los "cómplices pasivos de la dictadura -una forma de desenmascarar la colaboración-, en una carta abierta al dictador, "el padre castrador, el padre violador", acaso

Cambio 16, 26 febrero 1999.

Citado en Libération, 6 marzo 1999 (en adelante omitimos esta referencia). 
en respuesta a la que éste había enviado a los chilenos. El psicoanálisis colectivo, expresado por La Parra en Carta abierta a Pinochet. Monólogo de la clase media chilena con su padre, tiene el mérito de haber quebrado el silencio de la mayoría, y de haber identificado y definido a los colaboradores pasivos de la dictadura chilena en más breve plazo y con más lucidez que lo hiciera la "colaboración" con los fascismos europeos. No solo. Se atrevía a exhortar al "padre castrador" a decir la verdad, aunque en ningún momento pide justicia: "Si al menos, por azar, usted se pusiera a llorar... Usted no lo hará...Usted ha ganado" (Parra 1999). En el mismo sentido se podía leer en el órgano católico de la prensa francesa:

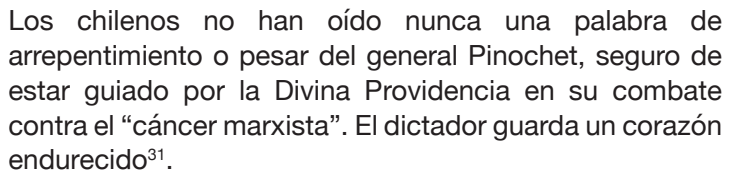
arrepentimiento o pesar del general Pinochet, seguro de estar guiado por la Divina Providencia en su combate contra el "cáncer marxista". El dictador guarda un corazón endurecido ${ }^{31}$.

Las denuncias de una parte de los católicos, incluida parte de la jerarquía chilena, no impedían la diferencia de postura en su seno, o las gestiones vaticanas en favor de la liberación del dictador, que denunciaba Le Monde ${ }^{32}$.

\section{Las dos memorias (1998-2000). La construcción del mito del Dictador}

Algo había cambiado en la sociedad chilena. La detención del dictador en Londres había abierto la puerta a una serie de cambios que se enracimaron desde entonces. Puso sobre el tapete la cuestión de los derechos humanos, soslayados desde 1992, pudo cambiar la actitud de muchos chilenos, que se interpelaron sobre la inmunidad, y empezó a variar, también, la actitud de la justicia.

Como resultado de su retención en Londres, se había debilitado la imagen del dictador. Antes de su regreso a Chile, algunos ya intuyeron que, muriera en exilio como él mismo había vaticinado, o regresara como un héroe a su país, el 'enfermo londinense' pertenecía ya al pasado.

\footnotetext{
Pinochet ha muerto simbólicamente, pero es un déspota ilustrado que se va como vencedor. Es un personaje que ha marcado la historia de Chile y la de América Latina. Aceptemos vivir con nuestras diferencias y nuestros odios, la democracia debe acabar con los simulacros de los falsos consensos (Liberation 1998).
}

Había afirmado un antiguo consejero de Allende $^{33}$.Después de la esperanza suscitada por la disposición judicial de los Lores, la decisión política británica se impuso. El dictador, verdadero "Lázaro resucitado" ${ }^{34}$ volvió verdaderamente a Chile. Habían contribuido a hacer gestiones a favor de su retorno, entre otros, el gobierno chileno, el presidente argentino, la influyente señora Thatcher, el Vaticano, el gobierno español y, acaso también, influyentes poderes económicos en Chile. Esto es lo que informaba la prensa, los archivos pueden guardar otros secretos.

La imagen triunfal de Pinochet se había deteriorado. Una memoria alternativa se puso en circulación inmediatamente para recuperar la imagen del dictador y para poder hacer frente al contra-mito que había emergido en torno a

El sociólogo Tomás Moulian, en Libération, 15 noviembre 1998.

34 Le Nouvel Observateur, 20 abril 2000. Sobre el tema del dictador de Chile como un Lázaro resucitado volverán varios textos, entre otros el de Carlos Franz, "El fantasma de Chile", en Letras libres (Edición España), n 72, septiembre 2007, pp. 6-7. 
él: "la caída de los dioses". Pero desde que se iniciaron los primeros juicios -en concreto por el asesinato de Letelier en Washington-, hasta cuando Pinochet comenzaba a "pertenecer al pasado", el mismo dictador había construido ya su propia imagen, como también lo habían hecho Mussolini o Franco (Passerini 1991; Southworth 2008; Reig Tapia 1996; Chamorro 1998; Zenobi 2011; Cazorla 2014; Moradiellos 2016): "He sido una buena persona. Saludo a las damas, acaricio a los niños, ayudo a los pobres. De hecho, soy un demócrata... a mi manera" y empezó a cambiar el uniforme por el traje civil.

El arresto británico del dictador fortaleció la consolidación de las dos memorias, frente a frente:

Se impone la idea según la cual el olvido constituye la prolongación del crimen; en el caso de los genocidas y de las prácticas de la desaparición de personas, es -en tanto que "borramiento" continuo de las huellas- prosecución activa y voluntaria del crimen, perpetuación infinita. Sin embargo, es de temer que este cuadro sea demasiado bello para ser verdadero y demasiado simple para encarar hoy los dilemas de la memoria colectiva, comprendida en la memoria de los crímenes de Estado (Brossat 2006: 18).

En Chile, hasta entonces, se habían divulgado oficialmente sólo hechos positivos y el éxito de la transición; en suma, el presente había desalojado de la escena al pasado, 'para evitar arañar en las viejas llagas', para 'olvidar y reconciliarse'. El dolor se calma poco a poco, añadían. Y, aunque a la altura de 1998 se seguía insistiendo en pasar la página, el olvido que se propugnaba no era total -era selectivo-, se trataba de borrar los atentados a los derechos humanos a la par que se exaltaba la imagen y la memoria del dictador que, argüían, pasaría a la historia como uno de los mejores gobernantes del siglo, 'por haber liberado a Chile del marxismo'. Los más próximos exaltaban su figura y edificaban su panegírico en vida:
Que muera en paz, en su cama, y todo el país se inclinará ante su féretro. El hará desfilar a todo el pueblo chileno, reconciliado, ante su cadáver, justificaban ${ }^{35}$.

Además, se invocaba en su haber cierto respaldo sociológico: esta buena imagen del dictador era defendida permanentemente por la cuarta parte de la población chilena, "un porcentaje inmutable". Se apelaba a la memoria para construir el mito. Ciertamente, una base muy sólida de Pinochet estaba representada por el $25 \%$ de los chilenos, que le consideraba "como uno de los mejores gobernantes del siglo". Mientras que para el $56 \%$ de las personas encuestadas, el golpe de estado "destruyó la democracia" y el $68 \%$ estimaba que la historia recordaría a Pinochet como un "dictador". El $62 \%$ consideraba que había que "juzgar a los responsables" y el $77 \%$ le consideraba responsable de los crímenes perpetrados bajo su mandato. La misma proporción aprobaba la decisión del gobierno de oponerse a la extradición a España.

En apoyo -indirecto- del ex dictador se expresó también entonces el Embajador chileno en USA, aunque no reivindicaría ya su imagen personal, pues -argüía- a Pinochet le amparaba la extraterritorialidad y sobraban las reivindicaciones. El embajador defendería, en cambio, la transición chilena, diferencia y cambio de sujeto que hemos percibido en otros testimonios y que implica una reivindicación indirecta. El diplomático proseguía que, en el contexto de un fenómeno tan extendido como las transiciones de las dictaduras a las democracias, Chile (atención, no decía:Pinochet) aportaba 'un balance más que honorable', había instituido una Comisión, había realizado juicios limitados y selectivos, en los límites de una

\footnotetext{
35 L'Express, 12 noviembre 1998, pp. 66-67.
} 
amnistía reducida. La transición pacífica había transcurrido en "la reconciliación sin justicia", o mejor, con "una justicia en los límites de lo posible", mal comprendida, aunque respondía a una necesidad absoluta -no especificaba de quién-.

En la transición chilena se había respondido a las exigencias de la justicia en el marco de una política garante de estabilidad, de progreso económico y de paz social. En el discurso del diplomático chileno, estos dos últimos eran valores del presente, mientras en otros discursos se atribuían al pasado dictatorial y a su necesario arrumbamiento en el desván del olvido. Con ello recurría al tan conocido ejercicio memorial, tan bien practicado por Franco, del recurso a la legitimación de ejercicio, legitimación por los hechos (Aguilar 2008), justificando la dictadura por el considerado "milagro económico":

Pero, sin duda, la tela más confusa con la que atavían al Chile de hoy es la sábana de seda del "milagro chileno". El país exitoso, "viable" -pronunciado muchas veces como "envidiable"-, es arropado ahora con una suerte de toga de alumno sabelotodo recién egresado de la escuela de la pobreza, admitido, por fin, y con honores, en la educación superior de los países desarrollados (Franz 2007: 7).

En plena crisis del asunto Pinochet, El Mercurio también había abierto sus páginas a un cambio en el objeto del recuerdo y en la reelaboración del mito. Tampoco se ocupó tanto del dictador arrestado -un recuerdo que resultaba poco reparador en ese momento-. Diluyó los juicios críticos a Pinochet en la tinta de calamar de otros genocidios perpetrados en el siglo XX, precisamente similares a los que acusaban al dictador ${ }^{36}$. Recordó a los europeos los

${ }^{36}$ "Un fallo histórico: Genocidio. Crónica y análisis del juicio a Etchecolatz. Fundamentos de la sentencia. Sus consecuencias sociales, políticas y jurídicas", en Puentes, $n^{\circ} 10$, octubre 2006 (Argentina). genocidios ingleses en Irlanda, los franceses en Argelia, y recordó Kosovo, que calificó como 'Auschwitz de fin de siglo'. Señalaba a Milosevic como el auténtico genocida, que había operado con toda impunidad en el corazón de la vieja Europa. El trabajo de sustitución del recuerdo no puede ser más evidente.

Los europeos harían mejor en arrepentirse que en pedir a Pinochet hacer penitencia en su lugar", escribía un militar que había sido portavoz en un gobierno Pinochet, recordando a Europa sus "pasados dolorosos" (Mink, Neumayer 2007).

Mientras el enfermo londinense seguía arrestado en su mansión, en Le Monde, Carlos Fuentes también abordó su figura y su obra a la luz de la historia. $Y$ mientras sus partidarios reforzaban su mito, el escritor elaboraba un contra-mito. Le comparó con personajes importantes, sobre todo por sus "tristes destinos". La estancia británica del dictador le hizo recordar a

(...) los macabros personajes shakespearianos, Macbeth o Ricardo III, bañados en sangre (...), inaccesibles en la sagrada crueldad de sus crímenes" ${ }^{37}$. Aunque a la mano de hierro de éstos, el chileno unía "un humor negro repugnante que ni Hitler ni Mussolini se hubieran permitido (Le Monde 1999) ${ }^{38}$.

En una revisión de la gloria del dictador y del mito elaborado sobre él, lo reducía a sus dimensiones humanas: No salvó a Chile de una dictadura marxista, de la que el pueblo hubiera sabido librarse democráticamente, añadía. Tampoco restauró la economía chilena "destruida por Allende". Para entonces eran ya conocidos y él recordaba el ataque frontal norteamericano y los procedimientos utilizados para bloquearla, no menos que los funestos resultados de los

\footnotetext{
Le Monde, 3 febrero 1999

38 Le Monde, 3 febrero 1999
} 
Chicago boys durante el periodo dictatorial (Lawner 2011). Y, por otro lado, se preguntaba, "¿la macroeconomía justificaba la violación masiva de los derechos humanos en Chile?". En un ejercicio de superposición de memorias, recurría a la comparación con Mussolini y Hitler, ahora en un afán de acentuar la faz negativa del dictador chileno. Aquí, más que un fenómeno de sustitución, como en el caso de El Mercurio, se produce el de superposición y el reforzamiento de memorias, las del pasado refuerzan al presente ${ }^{39}$.

Cuando el año 2000 se levantó la inmunidad parlamentaria al senador vitalicio el año 2000, éste reforzó de nuevo su figura, mientras robustecía la gloria y la memoria del periodo que presidió, en una permanente reelaboración del mito. Pues la memoria dictatorial, aunque erosionada, no cedía; el "enfermo londinense" seguía reivindicándola. Un trabajo fundamental para el mantenimiento del poder. El propio dictador estaba dispuesto a defenderse. Los argumentos son ya conocidos, se presentaba como el salvador del caos, del complot. Argumentos que ahora se esgrimían con mayor fuerza: "Es un complot dirigido a destruir la obra histórica del general Pinochet, para reivindicar a Allende y el socialismo", explicaba un diputado de Renovación Nacional.

Como durante su encierro en Londres, se aprestaba ahora a escribir otra carta abierta a los chilenos, reivindicando su figura y su papel histórico de "libertador de la patria". Pretendía contrapesar la que denominaba "propaganda socialista", la humillación que le infligía el

39 Para una explicación de estos conceptos y de otros manejados en el texto, especialmente los distintos trabajos de la memoria Cuesta 2008, especialmente el capítulo 2. Ver también: García Fernández 2014. juicio de su propio país. Contreras ya le había hecho responsable, Argentina solicitaba la extradición de éste, tras la condena a prisión perpetua, el responsable del asesinato del general Prats en Buenos Aires, perpetrado por la DINA. Ante la figura de anciano humillado, que había empezado a divulgarse, se presentó a sí mismo como un luchador: "He nacido para luchar, voy a defenderme ante los tribunales y a demostrar que soy inocente" 40 . Su propia frase es exponente de su debilidad, el "héroe" tenía necesidad de reivindicarse. La prensa francesa recordaba que habría de defenderse al menos de 179 causas presentadas contra él a fines del 2000. En su 85 aniversario, privado ya de la inmunidad, había asumido, "como presidente de la República, todos los hechos que se dice haber sido cometidos por las fuerzas armadas". Era un hecho excepcional. Para reivindicarse, mantenía los argumentos de siempre, especialmente el de la legitimidad de ejercicio. Se aprestaba a capitalizar el balance del "milagro económico" y su acción en los años 1973-1990:

(...) haber abierto el país a un nuevo campo de experimentación que las dictaduras vecinas -Uruguay, Brasil, Argentina- adoptaría a su vez: reducción del papel del Estado, flexibilidad del trabajo, baja de salarios, privatizaciones y aniquilamiento -a veces en la sangrede los sindicatos ${ }^{41}$.

Generando así un modelo económico citado como ejemplo. Invocaba en su apoyo a la Unión Patronal, que proclamaba: "ha generado cambios importantes y de éxito para el país"42. Manifestaba contar con el apoyo de los Estados Unidos, por los servicios prestados en la lucha

40 Le Monde, 11 agosto 2000; L'Humanité, 12-13 agosto 2000.

41 L'Humanité, 12-13 agosto 2000.

42 L'Humanité, 12-13 agosto 2000. 
contra la "subversión" en América Latina, otro de los éxitos de su mandato que no dudaba en capitalizar. A pesar de todos estos argumentos, ya no era fácil la recuperación de su imagen en el exterior. Desde su estancia en Londres, las representaciones gráficas que divulgaba la prensa mundial en viñetas o chistes dejaban muy mal parada la figura del dictador chileno.

Todavía a sus ochenta y ocho años, liberado por el Tribunal Supremo chileno por su "demencia moderada", el viejo general concedió una entrevista a una televisión norteamericana de habla hispana en la que seguía manteniendo su discurso:

No pienso pedir perdón a nadie. Por el contrario, corresponde a los otros pedirme perdón, a los marxistas, a los comunistas (...) No me gustaría que las generaciones futuras pensaran mal de mí.

Requería un lugar en la historia y en la memoria. Le Monde, faltando a su deseo y remedando una de sus frases en la que afirmaba sentirse "como un ángel", le denominaba "el ángel exterminador" 43 .

La aureola de Pinochet se había quebrado. Su larga detención había permitido a los chilenos encarase con su pasado. No así a sus partidarios, que también en Europa hicieron del regreso una aclamación, recuperando el relato heroico de sus gestas y su papel de personaje histórico del siglo XX chileno: "el retorno de Pinochet desencadena las masas "en su apoyo", la gran familia del pueblo chileno se reencuentra con su Tata (abuelo)", tituló en Francia National Hebdo ${ }^{44}$. Desde su regreso, al menos dos memorias

\footnotetext{
Le Monde, 12 julio 2003.
}

44 National Hebdo, 6 abril 2000. Episodio que quedaría grabado en la filmografía por Patricio Guzmán, como veremos más adelante. iniciaron caminos cruzados. Muchos estaban convencidos, y así lo escribían, de la imposibilidad de juicio a Pinochet en Chile. Además, se blindó aún más su inmunidad. La experiencia del riesgo londinense impulsó a sus partidarios a proponer una ley que defendiera aún más al dictador: los parlamentarios chilenos votaron una enmienda constitucional que concedía la inmunidad judicial a los expresidentes de la República. La constitución pinochetista se perfeccionaba a sí misma.

\section{En el nuevo siglo, refuerzo del olvido contra recuperación de la memoria y de la justicia}

“Él protegió a Caín contra el juez de instrucción, e hizo portar al asesino la pancarta de inmunidad", había escrito Juan Carlos Onetti.

En Chile no estaba ya en juego la estabilidad política. Aunque el ejército y las elites vigilaban, se había levantado el telón. Como los Lázaros bíblicos, los muertos y desaparecidos caminan con los brazos llenos de todos los derechos humanos, con la historia reencontrada ${ }^{45}$.

Carlos Fuentes -ya citado-, recurriendo a la literatura británica, le comparaba con Macbeth:

Como el fantasma de Banquo se apareció a Macbeth en el castillo de Dunsinane, los de Jara, Letelier, Prats, Leigthon, Scheneider, Violeta Parra y de otros cuatro mil chilenos vuelven para aterrar al tirano.

Los desaparecidos retornaban el presente penosamente. Satisfacción simbólica para unos, espina dolorosa para otros, la demanda de extradición de un dictador encanecido en el oficio ha devuelto, en las memorias o en el imaginario, ha evocado literalmente la figura

Politis, 28 enero 1999. 
del "desaparecido", del "desaparecido y de su doble" por retomar la acertada fórmula de Antonia García Castro (García Castro 1999: 42-49).

En efecto, noventa y dos quejas, depositadas en Chile contra Pinochet, quebraban el camino del olvido y propugnaban la verdad y el juicio por los crímenes -más de setenta ejecutados sin juicio- cometidos por la "Caravana de la muerte" en $1973^{46}$. Diecinueve víctimas no habían sido encontradas. Siete oficiales estaban ya detenidos por esta causa, entre ellos, un general confesaba haber recibido órdenes del antiguo dictador. El Tribunal de Apelación de Santiago inició el proceso para levantar la inmunidad parlamentaria a Pinochet. Era la primera vez que se realizaba un proceso similar en su propio país y se manifestaba una posición directa contra la amnistía. Desde 1999 la justicia chilena había aceptado una nueva interpretación de la amnistía de abril de 1978, que ahora ya no incluía la desaparición de personas, pues eran objeto de imprescriptibilidad. Los desparecidos clamaban justicia en la acusación de crímenes contra la humanidad. Todas las amnistías aprobadas hasta entonces se quedaban cortas ante la Convención Interamericana sobre Desaparición Forzada de Personas (1996).

Habían cambiado, además, la presidencia chilena y la coalición en el poder. El presidente Ricardo Lagos, recién elegido, recibiría al comandante de las Fuerzas Armadas, quien afirmaba que "las aguas no estaban tranquilas". El presidente ratificó la división de poderes,

46 En octubre de 1973, Cuadernos para el Diálogo publicó en España un número especial dedicado a Chile y titulado "Las trampas de la derecha", entre cuyos textos podía leerse el poema: "Coro: Murieron tres mil seiscientos. Uno tras otro. Tres mil seiscientos mataron. Uno tras otro". Cuadernos para el Diálogo, no 121, octubre 1973, "Especial Chile", la cita de la página 23. y la prensa occidental recogió con interés el discurso del nuevo presidente:

Le he dicho que Chile estaba en calma porque las instituciones funcionan. El poder judicial realiza su trabajo $y$, como hemos anunciado al mundo entero, todos los chilenos, sean humildes o poderosos, son responsables ante los tribunales. No interferiremos ante el poder judicial. Dejemos hablar a la justicia ${ }^{47}$.

La política de Lagos hacia las fuerzas armadas era delicada (Lagos 2013). En el Tribunal Supremo, catorce jueces frente a seis habían votado el levantamiento de la inmunidad parlamentaria del senador vitalicio. Meses antes, en el Tribunal de Apelación de Santiago, la proporción había sido de trece frente a nueve. Aunque no pueden olvidarse las presiones subterráneas y complejas sobre la justicia. Acaso por ello, la decisión tomada el día 1 de agosto no se hizo pública oficialmente hasta el 8. ¿Buscaba preparar a la opinión para una decisión importante, como un aterrizaje suave? ¿O minimizar el impacto? En efecto, lo tenía. El fin de la inmunidad marcará el de la impunidad. Abrió la vía a la justicia, al juicio, a la condena. Plantó ahora en suelo chileno la eterna cuestión de la memoria y la justicia: ¿era posible un proceso al hombre más fuerte de Chile desde hacía veinticinco años? El veredicto 'histórico' contemplaba dos hechos fundamentales, el 'derecho a saber la verdad' y la imprescriptibilidad.

El clima y el alcance de la medida anti-olvido hubieran sido impensables dos años antes; para algunos, incluso inimaginables cinco meses antes. El presidente Lagos repetía: "el país está en calma". Washington, que tanto había apoyado al dictador, saludó la decisión como "claramente histórica" e "importante para

\footnotetext{
La Monde, 29 abril, 12 mayo 2000.
} 
el desarrollo de los derechos humanos"48. El retorno del padre inauguraba la persecución del padre. El "intocable había pasado al rango del común de los mortales, más aún, estaba a punto de sentarse en el banco de los acusados"49, divulgaba Libèration.

El mismo día, en una posición más distanciada, Le Monde hacía un balance más crítico: "La sociedad chilena está lejos de estar reconciliada, las divisiones del pasado siguen presentes" 50 . En efecto, ante esta decisión de la justicia, las actitudes, como las memorias, volvieron a ser divergentes. Los partidarios de Pinochet reaccionaron con inquietud, indignación y pesimismo. Acusaron a la derecha de abandonar al dictador, a los jueces de venganza, y amenazaron con el retorno al clima de los años setenta-el recuerdo como intimidación política-. "No nos quedaremos con los brazos cruzados (...) vamos a volver al clima de los años 70 y a retornar a lo que ha pasado hace treinta años" ${ }^{\text {, }}$, informaba el mismo periódico francés.

Esta amenaza permite pensar en el caso español (González y Nicolás 2010). En las elecciones del 2000 había quedado de manifiesto que el electorado chileno de derechas, que había representado casi la mitad de los electores -48\%- ya no se identificaba todo él con el pinochetismo (Rubio Apiolaza 2013). Durante la campaña electoral, su candidato a la presidencia había hecho todo lo posible por distanciarse de Pinochet. Parecía recordar lo que la extrema derecha había argüido respecto a Franco en España: "Lo que necesitamos (...) no momias"

\footnotetext{
Libération, 9 agosto 2000.

Libération, 9 agosto 2000.

50 Le Monde, 9 de agosto 2000.

51 Le Monde, 9 de agosto 2000.
}

(Cuesta 2008: 366). Londres, el cambio de la legislación internacional y el tiempo habían contribuido a la desafección. Aunque no de todos. Los más fieles partidarios del dictador reaccionaron. Sus abogados cambiaron de estrategia, del "enfermo londinense" pasaron también a la recuperación de la imagen del dictador y de su memoria histórica, como hemos visto. Su defensa había puesto hasta ahora el acento en el ámbito personal, en su estado de salud. Ahora la minusvalía no interesaba, pues su incapacitación por los médicos le impediría defender su inocencia. Por lo que se despojó de la silla de ruedas en la que había llegado desde Londres y comenzó otra vez a andar, como un nuevo Lázaro. Se cambió la estrategia y se acentuó una línea política que reivindicara la figura histórica renovada del dictador y de su obra, apropiándose del discurso más activo entonces -el derecho a la verdad-: "En diversas tribunas políticas vamos a hacer conocer la verdad sobre la realidad del país antes de 1973". Se abrió un amplio debate histórico sobre el lugar de Pinochet en la historia de Chile.

Entre los que habían reclamado la verdad y la justicia -las asociaciones de derechos humanos especialmente- reinó esta vez el optimismo, el alborozo incluso. Para ellos, el episodio había marcado con el sello de la esperanza una nueva página de la historia chilena ¿Se abría una salida al pasado cerrado?

Este 8 de agosto quizá ha franqueado el cabo de la "transición", sobre la que planeaba la sombra del dictador. El país parece preparado para afrontar los fantasmas del pasado. $Y$ castigar a los asesinos ${ }^{52}$.

Chistian Kazandjian, "Pinochet face à ses crimes", L'Humanité, 9 agosto 2000. Libération, de la misma fecha, eligió un titular muy similar al texto mencionado: Oliver Bras, "Diez años después un país siempre en transición. La sombra de la dictadura pesa sobre una débil democracia". 
Conjeturaba el órgano del partido comunista francés. Se multiplicaban las investigaciones sobre los crímenes cometidos durante la dictadura y la búsqueda de restos en los cementerios oficiales o clandestinos, en los lechos de los ríos o en los descampados donde pudieran encontrarse los cuerpos.

La búsqueda del pasado no solo se ahondó en los espacios, en el suelo, buscando huellas, huesos y cuerpos. Se remontó además en el tiempo, como en Argentina, y buceó hasta la presencia del nazismo y su arraigo en suelo americano, también chileno. "Santiago de los nazis", así tituló un dossier de libros el periódico francés Libération, el 13 de julio del 2000, en pleno retorno de Pinochet a su país. Se hacía eco de cómo Victor Farías, autor polémico exiliado en Alemania, había desempolvado un tiempo que se remontaba a los años treinta y que revelaba las raíces de un pasado nazi también en núcleos chilenos (Farías 2000; $1987 ; 2010)$. Apoyado en un ingente número de documentos, desveló en su libro cómo desde los años treinta los nazis habían impregnado las colonias alemanas y los círculos de poder en Chile ${ }^{53}$. En una época en que empezaba a romperse el silencio, el descubrimiento de este pasado le quebró como una piedra al cristal, "en un país donde el silencio ha reinado tanto, es una victoria", concluía el dossier de Libération $^{54}$.

53 Víctor Farías recordaba a "su profesor de ética, un "católico hispano-fascista" que en 1946 hacía el saludo brazo en alto, "admiraba a Franco y más tarde sería un escriba de Pinochet". Libŭration, 13 julio 2000 .

54 Libération, 13 julio 2000.

\section{Las otras memorias}

En la otra orilla, con el recuerdo personal, la lucha por la verdad y por la justicia, afloraban otras memorias en el nuevo siglo y con el nuevo gobierno. El Museo Nacional de Historia era un exponente; entrado el nuevo siglo se aprestaba a completar la versión desarrollista, confortable y pacífica del país con otra más adaptada a la sociedad, con la presentación y visibilidad de los conflictos. La sociedad chilena parecía haber perdido el miedo, romper el silencio. Hablaba. En 2003 ocho generales confesaron la existencia de problemas de derechos humanos durante la dictadura. "La sombra de Pinochet comienza a alejarse" ${ }^{\prime 5}$, apreciaba la prensa francesa. Aunque permanecía su importante influencia. El exdictador aún vivo, sus bases sociales, su discurso, su obra heredada, desde la Ley de amnistía hasta la Constitución de 1980.

Pero en la medida en que la sombra del dictador se alejaba, reemergía el recuerdo de Salvador Allende (Boero 2008). Primero en el exilio; el exilio cultural rememoró su figura, en París se representaba una obra de teatro en $2003^{56}$, mientras se había iniciado la recuperación del exilio en la propia sociedad e historia chilenas. Durante la dictadura se habían visto obligados salir unos seiscientos mil chilenos. A su retorno, el gobierno de Lagos había tomado algunas medidas sociales en su favor.

El mundo entero, también las nuevas generaciones, han podido reflexionar sobre las múltiples memorias encontradas que emanan de la sociedad chilena. El cineasta Patricio Guzmán ya había puesto ante nuestros ojos

\footnotetext{
Le Monde, 12 julio 2003; La Croix, 31 agosto 2003.
}

56 Témoignage Chrétien, 4 setiembre 2003. 
esa aventura que supuso el Chile de Allende, filmando a diario y salvando las bobinas en el exilio, después. Su realizador corrió peor suerte, eliminado por la dictadura. No obstante, el testimonio subsistió (Alcázar 2013). Aquella historia quedó plasmada en el filme, La batalla de Chile, I, II, III (1973-1979), un documental con valor de testimonio insustituible ${ }^{57}$.

Guzmán, cuyo cine ha estado siempre a la búsqueda de memoria, lucha obstinada contra el olvido y deseo obstinado de justicia, se apresura a reunir fondos y testimonios ${ }^{58}$.

Se remontaba a la palabra viva de las víctimas o de sus familiares, mujeres en su mayoría, aunque también filmaba a los verdugos, como el documental de la Comisión de la Verdad sudafricana. Después de años de silencio, como tantos chilenos, el arresto londinense del dictador arrancó declaraciones a su director:

No soy un militante. Participo un poco en el rumor del mundo. Me considero sobretodo como un observador (...) El documental es un género abandonado en América Latina. Pero un país sin documentales es como una familia sin fotografías. Una memoria vacía, una historia sin imágenes $(\ldots)^{59}$

De este trabajo surgirá El caso Pinochet $(2001)^{60}$, filmado al retorno del dictador a Chile, que pretendía indagar entre los partidarios del dictador, los que justificaban su acción o le admiraban: I love Pinochet, recoge, como en su

57 El documental La batalla de Chile ha recibido innumerables premios, que no podemos reseñar aquí. También ha recibido multitud de premios su película Chile, la memoria obstinada, de 1997.

58 Télerama, 10 Octubre 2001.

59 Тйlerama, 10 0ctubre 2001.

60 Film que completa otros testimonios personales de Guzmán en Una historia chilena. Puede verse también: Muñoz, Heraldo, La sombra del dictador: una memoria poltitica de la vida bajo el rŭgimen de Augusto Pinochet. Barcelona: Paidós, 2009. título, las aclamaciones de sus partidarios a su llegada. El discurso de la dictadura aparece aquí en todo su esplendor: Pinochet ha salvado al país del comunismo, peligro siempre amenazador, para ello la necesidad de la instauración de un poder fuerte, que se completa con el culto al 'salvador'.

"Y ¿los crímenes? Son "invenciones" para algunos, "lamentables" para otros, "inevitables" para todos" ${ }^{1}$, constataba Le Monde, poniendo de relieve cómo seguían confrontándose una multiplicidad de memorias en la democracia chilena.

\section{Una reflexión incompleta}

A modo de balance provisional, puede percibirse que la transición chilena, continuista, sin ruptura, vigilada bajo la sombra del dictador y de la legislación heredada, bajo los discursos de olvido y amnistía, impulsados desde el poder y en gran parte de la sociedad, sirven de obstáculo a la justicia, obstáculos puestos por la instituciones heredadas -tanto en el poder judicial como en el legislativo elegido democráticamente-, jalonan una transición que cristalizará en una periodo de lucha por la verdad, aunque sin aplicar la justicia. El comodín, lugar común, de la 'reconciliación' recubre ese tiempo de amnistía, de búsqueda de la verdad y de imposibilidad de justicia, reclamada de forma minoritaria por las víctimas y por sus asociaciones. A pesar de las políticas memoriales del periodo transicional, "la otra memoria", ante las dificultades de la política interior, reclamará la justica en el exterior.

\footnotetext{
Le Monde, 25 noviembre 2001.
} 
El inicio del juicio a Manuel Contreras en Chile, en 1995, con la anuencia de los Estados Unidos, inaugura un nuevo periodo de lucha por la justicia que llegará a un momento clave con el arresto de Pinochet en Londres. Nudo gordiano de la encrucijada memorial chilena, esta atormentada estancia londinense del dictador chileno sirve de catalizador a las narrativas y al discurso memorial chileno. Londres quiebra en Chile la dominante del olvido-silencio, impuesta por una transición vigilada desde aquel presente, e intensificará la lucha por el recuerdo y la verdad, especialmente por la justicia. Las memorias dominadas conquistarán terreno y revertirán los modelos y los mitos: de la reconciliación, del milagro económico, de la dictadura y de la transición modélica. Con ello se quiebran también los soportes del mito erigido sobre el dictador, que aparece ahora bajo la imagen de un ex dirigente perseguido y enfermo.

La elaboración del contra-mito del dictador gana terreno: del padre, al padre castrador, del ángel al ángel exterminador, representaciones ante las que Pinochet y sus partidarios han de reduplicar los esfuerzos y remodelar los discursos para reforzar el mito que se desvanece. A los trabajos de olvido, recuerdo, elaboración de mitos y contra-mitos, se añadirán otros más, los de cambio, sustitución y superposición de memorias; a todos estos 'trabajos de la memoria' acuden partidarios y detractores del dictador para seguir manteniendo viva la narración, después del episodio londinense.

En el nuevo siglo, al menos dos, o mejor una pluralidad de memorias, abren paso al juicio y a la justicia. El soporte fílmico es un buen exponente de ello. La memoria es una buena encrucijada de vectores y de conflictos que se ha demostrado estos años como un actor fundamental. Pero la retención de Pinochet en Londres desborda la problemática de la memoria y la de un solo país. Incide en las relaciones entre instituciones estatales, en las relaciones inter-estatales y coincide con la justicia transnacional, que se institucionaliza por las mismas fechas en un órgano internacional.

\section{Bibliografía}

Alcàzar, J. del. 2013. Chile 73. Memoria, impactos y perspectivas. Valencia: Universitat de València.

Alcázar Garrido, J. del. 2013. Chile en la pantalla. Cine para escribir y para enseñar la historia (1970-1998). Valencia:Universitat de València.

Amira, L. 1981. "La política de Estados Unidos hacia la subregión del cono sur", América Latina. Estudios y perspectivas. México. № 3 .

Aguilar, P. 2008. Políticas de la memoria y memorias de la política. Madrid: Alianza editorial.

Alvarez Vallejos, R. E. 2011. Arriba los pobres del mundo. Cultura e identidad política del Partido Comunista de Chile entre democracia y dictadura. 1965-1990. Santiago de Chile: LOM.

Barahona de Brito, A. 2002. "Verdad, justicia, memoria y democratización en el Cono Sur", en Barahona de Britto, A., Agilar Fernández, Paloma; y González Enríquez, C., Las políticas hacia el pasado. Juicios, depuraciones, perdón y olvido en las nuevas democracias. Madrid: Istmo.

Bédarida, F. (Dir.) 1996. Touvier, Vichy et le crime contre I'humanité: le dossier de l'accusation. Paris : Seuil.

Boero, M. 2008. Recuerdos pendientes: teología, sociedad y fe en la memoria cristiana de Chile: en el centenario de Salvador Allende (1908-1973). [Moraleja de Enmedio, Madrid]: Arco.

Brossat, A. 2006. "La memoria colectiva. Entre la resistencia y la gubernamentalidad". Puentes, № 19, diciembre.

Buriano Castro, A.; Dutrénit Bielous, S; Vázquez Valencia, D., (Ed.). 2015. Política y memoria: a cuarenta años de los golpes de Estado en Chile y Uruguay. México: Instituto Mora.

Candia, J. 2013. "15 años de la detención de Pinochet en Londres: Expertos destacan importancia del proceso para la justicia universal". Radio Universidad de Chile, 13 octubre. http://radio. uchile.cl/2013/10/16/15-anos-de-la-detencion-de-pinochet-en- 
londres-expertos-destacan-importancia-del-proceso-para-lajusticia-universal/ (Consultado en agosto de 2016).

Cavallo, A. 1998. La historia oculta de la transición. Memoria de una época, 1990-1998. Santiago: Grijalbo.

Cazorla Sánchez, A. 2014. Franco: biografía del mito. Madrid: Alianza Editorial.

Chaves Palacios, Julián (coord.), 2010. La larga memoria de la dictadura en Iberoamérica. Argentina, Chile y España. Buenos Aires: Prometeo Libros.

Comité de Santa Fe. 1990. "Une stratégie envers l'Amérique latine". La Pensée. N No274.

Constable, P.; Valenzuela, A. 2013. Una Nación de enemigos. Chile bajo Pinochet. New York: Norton, 1993 (última edición en español: 2013).

Cuesta, J. 2007. "Las capas de la memoria". Contemporaneidad, sucesión y transmisión generacionales en España (1931-2006)". HISPANIA NOVA. Revista de Historia Contemporánea. Número 7. http://hispanianova.rediris.es/7/ dossier/07d009.pdf (Consultado en agosto 2016).

Cuesta, J. 2008. La Odisea de la memoria. Historia de la memoria en España, siglo XX. Madrid: Alianza editorial.

Chamorro, E. 1998. Francisco Franco: anatomía de un mito. Barcelona: Plaza \& Janés.

Duroux, R.; Urdician, S. 2010, Les Antigones contemporaines (de 1945 à nos jours). Clermont-Ferrand : Presses Universitaires Blaise Pascal.

“Especial Chile". (1973). Cuadernos para el Diálogo, n 121, octubre. "Estudio sobre el derecho a la verdad. Texto extractado del Informe del Alto Comisionado de las naciones Unidas para los derechos Humanos", http://www.mecd.gob.es/cultura$\mathrm{ecd} / \mathrm{dms} / \mathrm{mecd} /$ cultura-mecd/areas-ultura/patrimonio/mc/ patrimonioculturale/n-1/capitulos/06_PCE1_Derecho_verdad.pdf; (Consultado en agosto de 2016).

Farías, V. 2000, Los nazis en Chile. Santiago: Editorial Planeta (reedición: 2015).

Farías, V. 1987. Heidegger y el nazismo. Paris: Verdier.

Farías, V. 2010. Heidegger y su herencia. Los neonazis, el neofascismo y el fundamentalismo islámico. Madrid, Tecnos.

Fermandois, J. (dir.); Stuven, A. M. (coord.). 2013-2015. Historia contemporánea de Chile. T. 5. La búsqueda de la democracia, 1960-2010. Madrid, Fundación MAPFR. Barcelona: Taurus.

Finet, H. ; Desvois F. (Dir.) 2014. Chili 1973-2013: mémoires ouvertes Chile 1973-2013.Paris : L'Harmattan.

Franco, M. 2006. "Los exiliados argentinos en Francia. El descubrimiento de los derechos humanos". Puentes $\mathrm{N}^{\circ} 19$, diciembre, pp. 58-65.

Franz, C. 2007. "El fantasma de Chile", en Letras libres (Edición España) No 72, septiembre, pp. 6-7.

Garcés, J. E. 2013. Allende y la experiencia chilena. Las armas de la política. Santiago de Chile, Siglo XXI.

García Castro, A. 1999. "Pour une histoire officieuse des 'disparitions' en Amérique latine ", en Matériaux pour l'histoire de notre temps, $\mathrm{N}^{\circ} 54$, avril-juin, pp. 42-49.

García Castro, Antonia. 2011. La muerte lenta de los desaparecidos en Chile. Santiago de Chile: Cuarto Propio.

García Fernández, G. 2014. El pasado como una lección del presente: una reflexión histórica para el Chile actual. Alcalá de Henares, Madrid: Universidad de Alcalá. Disponible también en sitio web. Gárate Chateau, M. 2012. La revolución capitalista de Chile (1973-2003). Santiago de Chile: Universidad Alberto Hurtado.

Garretón, M. A., Merino; Lagos, M.; y Méndez, R. 1994. Los chilenos y la democracia: la opinión pública, 1987-1994. Santiago: Participa.

Garretón M. A. 2012. Neoliberalismo corregido y progresismo limitado. Los gobiernos de la Concertación en Chile, 1990-2010. Santiago de Chile: Arcis.

Gómez Leyton, J. C. 2010. Política, democracia y ciudadanía en una sociedad neoliberal (Chile: 1990-2010). Santiago de Chile: Arcis.

González Martínez, C., Martín, E. (eds.) 2010. "Procesos de construcción de la democracia en España y Chile", Dossier de AYER, $\mathrm{n}^{\circ} 79$, (3).

González Quintana, A. 2008. Gestión de los archivos de los Servicios de Seguridad del Estado de los desaparecidos regímenes represivos. París: Consejo Internacional de Archivos.

González Quintana, A. 2009. Políticas archivísticas para la defensa de los derechos humanos. Actualización y ampliación del informe elaborado para UNESCO y el Consejo Internacional de Archivos (1995) sobre Gestión de los archivos de los Servicios de Seguridad del Estado de los desaparecidos regímenes represivos. Consejo Internacional de Archivos, París, 2008.

Harmer, T., Riquelme, A. 2014. Chile y la Guerra Fría global. Santiago: RIL editores.

Hoppe, López, Montecino, Pérez. 2013. Chile 1973-1990. La dictadura de Pinochet. Santiago de Chile: LOM.

Huneeus, C. 2014. La democracia semisoberana: Chile después de Pinochet. Santiago de Chile: Taurus.

Jean, J. P. y Salas, D. 2002. Touvier, B., P., Des procès pour la mémoire. Paris : Autrement.

Juliá, S. 2004. Historia de las dos Españas. Madrid: Taurus.

Lagos Escobar, R. 2013. Así lo vivimos. La vía chilena a la democracia. Santiago de Chile: Taurus

Lambert, B. 1991. Dossiers d'accusation : Bousquet, Papon, Touvier. Paris, Éditions de la Fédération nationale des déportés et internés résistants et patriotes.

Lawner, M. 2011. Orlando Letelier: el que lo advirtió. Los Chicago Boys en Chile. Santiago de Chile: LOM.

Lefranc, S. 2002. Politiques du pardon. Paris : PUF.

Lira, E., Loveman, B. 2014. Poder judicial y conflictos políticos (Chile: 1925-1958). Santiago: LOM.

Massardo, J. 1999. "Les rapports entre les Etats-Unis et l'Amérique latine pendant la guerre froide", Matériaux pour l'histoire de notre temps, ${ }^{\circ}$ 54, avril-juin, pp. 3-8.

Mignone, E. y Conte Mc Donell, A. 2006. Estrategia represiva de la dictadura militar. La doctrina del paralelismo global. Buenos 
Aires: Colihue.

Mink, G. y Laure Neumayer, L. (dir.). 2007. L'Europe et ses passés douloureux. Paris : La Découverte.

Moradiellos, E., (dir.). 2016. Las caras de Franco: una revisión histórica del caudillo y su régimen. Tres Cantos, Madrid: Siglo XXI de España.

Morales, S. 2005, "La sociedad fue educada para ser indiferente", Puentes, $\mathrm{n}^{\circ} 16, \mathrm{pp} .12 .13$.

Moulian, T. 1997. Chile actual, anatomía de un mito. Santiago de Chile: ARCIS-LOM.

Muñoz, H. 2009. La sombra del dictador: una memoria política de la vida bajo el régimen de Augusto Pinochet. Barcelona: Paidós.

Naqvi, Y. 2006. "El derecho a la verdad en el derecho internacional: ¿realidad o ficción?", International Review of the Red Cross, $n^{\circ} 862$, junio.

https://www.icrc.org/spa/assets/files/other/irrc_862_naqvi. pdf; (consultada el 10-8-2016).

Parra, Marco Antonio de la. 1999. Carta abierta a Pinochet. Monólogo de la clase media chilena con su padre. Paris : Editions la Serpent à Plumes.

Paris, Robert. 1999. "Présentation", Matériaux pour l'histoire de notre temps, $\mathrm{n}^{\circ} 54$, avril-juin, p. 2.

Passerini, L. 1991. Mussolini immaginario, storia de una biografia, 1915-1939. Roma-Bari, Laterza.

Reig Tapia, A. 1996. Franco "Caudillo": mito y realidad". Madrid: Tecnos.

Riquelme, A. 1999. "La transition démocratique au Chili et la fin de la guerre froide", en Matériaux pour l'histoire de notre temps, $\mathrm{n}^{\circ}$ 54, avril-juin, pp. 22-25.

Rojas Mix ; M. 2005. "América Latina. Una tipología de las dictaduras", Puentes, №. 16, diciembre, pp. 14-23.
Rojas Mix, M. 2007. El dios de Pinochet. Fisonomía del fascismo iberoamericano. Buenos Aires: Prometeo libros.

Rousso, H. 1987a. Le syndrome de Vichy (1944-1987). Paris : Le Seuil.

Rousso, H. 1987b. La collaboration. Paris : M. A. Editions.

Rousso, H., Conan, E. 1994. Vichy, un passé qui ne passe pas. Paris: Fayard.

Rubio Apiolaza, P. 2013. Los civiles de Pinochet: la derecha en el régimen militar chileno, 1983-1990. Santiago de Chile: Centro de Investigaciones Diego Barros Arana.

Salazar, G. 2012. Dolencias históricas de la memoria ciudadana (Chile, 1810-2010). Santiago de Chile: Editorial Universitaria.

Southworth, H. R. 2008. El mito de la cruzada de Franco: crítica bibliográfica. [Paris], Ruedo Ibérico, [1963]. Barcelona: Debolsillo.

Steiner, G. 2010. Les Antigones. Paris : Gallimard. 2004 (1984 $1^{\circ}$ édition).

Stern, Steve J. 2010. Reckoning with Pinochet. The Memory Question in Democratic Chile, 1989-2006. Book three of the trilogy: The Memory box of Pinochet's Chile. Durham: Duke University Press.

Torreblanca Gonzales, Luis Giancarlo. (2012/2013). "El derecho a la verdad en el ámbito iberoamericano" (Right to the True in Iberoamerica), lus Humani. Revista de Derecho, Vol. 3, págs. 9-35, https://dialnet.unirioja.es/descarga/articulo/4999993. pdf; (consultada en agosto de 2016).

Zenobi, L. 2011. La construcción del mito de Franco: de jefe de la legión a caudillo de España. Madrid: Cátedra.

Valla, J. C. 1996. Affaire Touvier : la contre-enquête. Paris : Éditions du Camelot.

Varas, A. 2012. La democracia frente al poder. Chile 19902010. Santiago de Chile: Catalonia. 
